Original Research Paper

\title{
Key Structural Aspects for Adaptive Facades - Activity Progress from the EU-COST Action TU1403 'Structural' Task Group
}

\author{
${ }^{1}$ Chiara Bedon, ${ }^{2}$ Dániel Honfi, ${ }^{3,4}$ Marcin Kozłowski, ${ }^{5}$ Klára Vokáč Machalická, \\ ${ }^{6}$ Filipe Santos, ${ }^{7}$ Thomas Wüest, ${ }^{8}$ Martina Eliášová and ${ }^{5}$ Miroslav Vokáč \\ ${ }^{I}$ Department of Engineering and Architecture, University of Trieste, Trieste, Italy \\ ${ }^{2}$ RISE Research Institutes of Sweden, Gothenburg, Sweden \\ ${ }^{3}$ Faculty of Civil Engineering, Silesian University of Technology, Gliwice, Poland \\ ${ }^{4}$ Faculty of Engineering, Lund University, Lund, Sweden \\ ${ }^{5}$ Klokner Institute, Czech Technical University in Prague, Prague, Czech Republic \\ ${ }^{6}$ CERIS and Faculdade de Ciências e Tecnologia da Universidade NOVA de Lisboa, Lisbon, Portugal \\ ${ }^{7}$ Institute of Civil Engineering, Lucerne University of Applied Sciences and Arts, Lucerne, Switzerland \\ ${ }^{8}$ Faculty of Civil Engineering, Czech Technical University in Prague, Prague, Czech Republic
}

Article history

Received: 14-05-2018

Revised: 02-06-2018

Accepted: 20-06-2018

Corresponding Author:

Chiara Bedon

Department of Engineering and

Architecture, University of

Trieste, Trieste, Italy

Email: chiara.bedon@dia.units.it

\begin{abstract}
Adaptive facades are getting more and more widespread in modern buildings. These facade systems, among many others, need to fulfil the requirements of several structural considerations, such as structural safety, serviceability, durability, robustness and fire safety, being typically defined for standard facades and building enclosures in general. The current paper discusses special structural characteristics which need to be taken into account when designing adaptive facades and summarizes some recent efforts of the activities in progress carried out by the 'Structural' Task Group (TG2.4) of the European COST Action TU1403 'Adaptive Facades Network'.
\end{abstract}

Keywords: Adaptive Facades, Structural Design, Testing Methods, Numerical Modeling, Classification

\section{Introduction}

Modern adaptive facades can significantly improve energy and thus cost, efficiency of both new and refurbished buildings by responding to the changes in the outdoor conditions. Furthermore, they can provide healthy and comfortable indoor environment to the building occupants, by adjusting the response to their needs.

As the main function of facades is to separate the indoor from the outdoor environment, their performance has a major impact to the building's energy usage is extremely important for reaching the European Commission's ambitious climate and energy targets by 2020 (EC, 2010), as well as to follow the 2050 energy roadmap goals (EC, 2012).

However, another important function of facades is to transfer various design loads (to the building skeleton) and to accommodate movements due to the same actions, being characterized by different features as in the case of self-weight, wind, earthquake loads, as well as thermal actions, extreme mechanical loads, etc. (see for example (Zhang \& Bedon, 2017; Bedon et al., 2018d; etc.). Depending on the type and level of adaptivity of a given facade, such a structural demand could lead to challenges during the overall design process. On the other hand, structural adaptivity can lead to a more efficient static and dynamic response under varying loading conditions, i.e. increase resistance in case of extreme events and/or provide fail-safe collapse mechanisms, thereby enhancing structural robustness.

Large amount of knowledge and information exists regarding various aspects of adaptive facades. This includes structural considerations among universities, research institutions, consultants and other industry players in Europe (and worldwide). However, such a knowledge and information, as well as the related expertise and resources, are actually scattered throughout the continent. To share these knowledge and 
ideas and organize European research and development efforts, the EU-COST Action TU1403 'Adaptive Facades Network' was created in the area of adaptive facades technologies (COST Action TU1403, 2014).

In this study, some general information about the European TU1403 network is given, including an activity progress on the work of its 'Structural' Task Group. Moreover, general definitions and concepts of adaptive facades, as well as examples and basis of structural design are given, including preliminary discussion on experimental testing and numerical modelling aspects.

\section{TU1403 'Adaptive Facades Network' and 'Structural' Task Group: goals and activities}

\section{Background, Aims and Forming of the Task Group}

The European COST Action TU1403 'Adaptive Facades Network' has been established in 2014, with the main objective to exploit the estimated economic potential of adaptive facade systems (http://www.tu1403.eu; http://www.cost.eu/COST_Actions/tud/TU1403). Major activities from the Action include:

- Harmonization, sharing and dissemination of technological knowledge between research centers as well as research centers and industries

- Development of novel concepts, technologies and new combinations of existing technologies for adaptive facades

- Development of new knowledge with regards to effective evaluation tools and design methods

Within the TU1403 network, it has been recognized that there is a need to account for structural aspects, when it comes to development, design, testing and standardization of adaptive facades. Therefore, the 'Structural' Task Group (TG2.4) has been detected as a sub-group of Working Group 2 (WG2), 'Component performance and characterization methods' and has been intended to act transversely within the network (Table 1).

The main goal of WG2, in particular, is to provide a unified approach for characterizing and evaluating the performance of adaptive and multi-functional facades, at the component level. This includes the various physical characteristics that affect the wide range of transient performance requirements of facades, hence major efforts are aimed to:

- identify for each aspect of facade performance (energy efficiency, structural, safety, fire, weather protection, durability, aesthetics) where the adaptive technologies would be most beneficial

- establish and standardise numerical and experimental ways of characterizing their performance (with an emphasis on performance related to energy efficiency)

- evaluate the suitability of conventional performance parameters to fully address the behaviour of adaptive facades

- develop new metrics that are able to capture the transient and multi-parameter performance of adaptive façades and thereby enable quantitative comparisons between different facades, where the adoption of conventional metrics is not satisfactory

- develop new numerical tools for evaluating the most promising adaptive technologies

The main aim of TG 2.4, in this context, is to assess the structural and durability domains, in terms of experimental testing, numerical modelling, classification, definitions, etc.

\section{Current Outcomes from TG2.4}

So far, TG2.4 actively contributed to the Action initiatives in several forms, including the Educational Pack (EP) in progress (http://www.tu1403.eu). The EP consists of lectures and educational material, such as pictures, design guides, training courses for new modelling techniques and experimental techniques, metrics for classification, etc.

The EP, in this regard, is expected to enable universities (both involved or external to the Action) to implement the adaptive facades knowledge into engineering and architecture programs, for dissemination at undergraduate and graduate levels. It is also expected that Early Stage Researchers and practicing engineers or architects could take advantage from the EP, to extend their knowledge on adaptive facades.

Table 1: Overview of Working Groups (WGs) for the COST Action TU1403

\begin{tabular}{|c|c|c|}
\hline WG & Topic & \\
\hline WG1 & Adaptive technologies and products & \\
\hline \multirow[t]{4}{*}{ WG 2} & Component performance and characterization methods & \\
\hline & Performance metrics and requirements & TG2.4 - Structural aspects \\
\hline & Simulation tools for adaptive performance assessment & \\
\hline & Experimental procedures for the evaluation of adaptive facades & \\
\hline WG 3 & Whole building integration and whole-life evaluation methods of adaptive facades & \\
\hline WG 4 & Dissemination and future research & 7 \\
\hline
\end{tabular}


TG2.4 also actively participated to the first successful COST Training School 'Adaptive Facades Network', being organized at HafenCity University (Hamburg, Germany, September 2016). A lecture focused on structural aspects and case studies for adaptive facades was given by Dr. Bedon, including fundamentals, numerical procedures, design philosophy, etc. The second Training School edition is planned for September 2018, at Belgrade University (Serbia).

So far, some of the collected TG outcomes and efforts have been already published in international conference proceedings, like for example:

\section{5}

- TU1403 Industry Workshop, TU Delft (The Netherlands), September

- IMST2015 - $2^{\text {nd }}$ International Conference on Innovative Materials, Structures and Technologies, Riga Technical University (Latvia), October

\section{6}

- Challenging Glass 5 - International Conference on the Architectural and Structural Application of Glass, Ghent University (Belgium), June

- ESAT2016 - $2^{\text {nd }}$ International Conference on Engineering Sciences and Technologies, Technical University of Košice (Slovak Republic), July

\section{7}

- ICSMESP2017 - International Conference on Structural and Mechanical Engineering for Security and Prevention, CTU Prague (Czech Republic), June

- M2D2017 - $7^{\text {th }}$ International Conference on Mechanics and Materials in Design, University of
Porto and University of Toronto, Albufeira (Portugal), June

- $\quad A B 2017-4^{\text {th }}$ International Conference on Structural Adhesive Bonding, Faculty of Engineering, University of Porto (Portugal), July

- Eurosteel $2017-8^{\text {th }}$ European Conference on Steel and Composite Structures, Copenhagen (Denmark), September

- NE-XT Facades Conference 2017 (TU1403 MidTerm Conference), Munich (Germany), November

2018

- Places and Technologies 2018 - $5^{\text {th }}$ International Academic Conference on Places and Technologies, Belgrade University (Serbia), April

- Challenging Glass 6 - International Conference on the Architectural and Structural Application of Glass, TU Delft (The Netherlands), May

- ECMS2018 - $3^{\text {rd }}$ International Electronic Conference on Materials Science, May (electronic event)

- EURADH2018/CLBA2018 - $12^{\text {th }}$ European Adhesion Conference and Luso-Brazilian Conference on Adhesion and Adhesives, University of Lisbon and University of Porto, Lisbon (Portugal), September

- FACADE 2018 - Final conference of COST Action TU1403 'Adaptive Facades Network', Lucerne University of Applied Science and Arts (Switzerland), November

Major topics of each presented contribution are summarized in Table 2.

In the same period, several documents from TG2.4 members have been published (or are currently under review) for publication in peer-reviewed, international scientific journals (see Table 3 ).

Table 2: TG2.4 papers published in international Conference Proceedings (listed by year and alphabetical order, grouped by topic)

\begin{tabular}{ll}
\hline Paper & Topic \\
\hline Bedon et al. $(2015)$ & Passive and active control systems for glass facades mitigation \\
Cruz et al. $(2015)$ & Connections \\
Bedon et al. $(2017 \mathrm{a})$ & Thermo-mechanical assessment of \\
Bedon et al. $(2018 \mathrm{c})$ & GFRP-glass sandwich facade components \\
Bedon et al. $(2017 \mathrm{~d})$ & Experimental testing, numerical \\
Kozłowski et al. $(2018)$ & modelling and classification of adaptive facades \\
Jordão et al $(2015)$ & Adhesive connections \\
Machalická and Eliášová (2015) & (experimental testing and/or numerical modelling)
\end{tabular}

Machalická et al. (2015)

Firmo et al. (2016)

Pravdová et al. (2016)

Rodrigues et al. (2017)

Bedon et al. (2018b)

Machalická et al. (2017a, 2017b, 2017c, 2017d)

Kozłowski et al. (2015)

Rajčić and Žarnić (2015)

Timber-glass structural assemblies under ordinary or extreme loads 
Table 3: TG2.4 papers published in peer-reviewed scientific journals (listed by year and alphabetical order, grouped by topic)

\begin{tabular}{ll}
\hline Paper & Topic \\
\hline Santos et al. $(2016)$ & Active control systems for glass facades mitigation \\
Bedon $(2017)$ & Facades and/or facade components under extreme loads \\
Bedon et al. $(2017 \mathrm{~b}, 2017 \mathrm{c})$ & \\
Kalamar et al. $(2017)$ & \\
Bedon t al. $(2018 \mathrm{a}, 2018 \mathrm{~d})$ & Connections \\
Bedon and Santarsiero $(2018 \mathrm{a}, 2018 \mathrm{~b})$ & \\
Santarsiero et al. $(2018)$ & Adhesive connections (experimental testing and/or numerical modelling) \\
Machalická et al. $(2018 \mathrm{a}, 2018 \mathrm{~b})$ &
\end{tabular}

Table 4: COST networking support for Short-Term Scientific Missions within TG2.4 (listed by year)

\begin{tabular}{lll}
\hline Year & Topic & Involved Institutions \\
\hline 2015 & $\begin{array}{l}\text { Numerical modelling of structural adhesives for } \\
\text { hybrid steel-glass beams }\end{array}$ & Univ. of Coimbra (PT) and Univ. of Trieste (I) \\
2016 & $\begin{array}{l}\text { Coupled structural \& thermal optimization of a } \\
\text { multifunctional building skin }\end{array}$ & $\begin{array}{l}\text { Univ. of Trieste (I) and Univ. of Cambridge (UK) } \\
\text { Silesian Univ. of Technology (PL) and Univ. of Trieste (I) } \\
\text { Univ. of Trieste (I) and RISE (SE) }\end{array}$ \\
\hline $\begin{array}{l}\text { Coupled thermo-mechanical models for structural glass } \\
\text { Thermo-mechanical numerical modelling of adaptive } \\
\text { facade assemblies under high temperatures and fire }\end{array}$ & \\
\hline
\end{tabular}

Additional financial support from COST offered further successful networking opportunities, in the form of Short-Term Scientific Missions (four in total, see Table 4), as well as a conference grant for Early Career Researchers (Dr. Kozłowski the beneficiary in April 2018 , for the oral presentation of a TG2.4 contribution at the international event 'Places and Technologies 2018', Belgrade University, Serbia www.placesandtechnologies.eu).

From Table 4, it is apparent that a main focus of the 'Structural' Task Group concerns with the effect of temperature variations on the structural performance of constructional systems, especially for glass elements. This could be particularly important, for example, for modern energy efficient glass facade systems in case of extreme temperatures, as a result of changing climate or accidental fire scenarios.

Further research topics - as also partly emphasized in Table 2 and 3 - include the performance of several connection types and systems at the component and assembly levels (especially adhesives), with careful consideration for long-term effects and ageing.

Another set of issues addressed by TG2.4 is then related to facades where the load-bearing structural system adapts to changing conditions, i.e. with regards to loading. This typically includes non-traditional materials and hybrid structural components, as also summarized in the following sections.

\section{General Definitions and Concepts for Adaptive Facades}

\section{Adaptive Facades}

Adaptive facades have been an attractive topic in research dealing with the behavior and performance of buildings, in the recent years (Loonen et al., 2013; Modin, 2014; Favoino et al., 2015; Aelenei et al., 2016; Udrea et al., 2016; Marysse, 2016; Attia et al., 2017; etc.). However, or rather naturally, what adaptivity actually refers to depends on the particular research topic and/or the specific application. Therefore, it is important to define a common terminology with the relevant definitions, so to develop a common understanding among researchers and practitioners with different background and focus.

A rather generic definition of adaptivity for facades and building envelopes is given by Loonen et al. (2013), as the ability to change their functions, features or behavior over time in response to transient performance requirements and boundary conditions, with the aim of improving the overall building performance'.

The above general definition is also adopted by Aelenei et al. (2016), with a further specification for the functional requirements which adaptivity aims to improve, such as heat, air and water vapor flow, rain penetration, solar radiation, noise, fire, strength, stability and aesthetics, etc.

Despite these rather broad definitions, most of the scientific papers available in literature and related to facade adaptivity typically focus on energy, climate and comfort related aspects (i.e., energy performance, thermal comfort, Indoor Air Quality (IAQ), visual and acoustic performance), typically characterized by gradual changes in the environment (see for example (Hasselaar \& Looman, 2007; Kim, 2013; Park \& Dave, 2014; Barozzi et al., 2016; Attia, 2017; Balocco \& Petrone, 2017; etc.). However, adaptiveness can be beneficial regarding the safety and robustness of buildings, since commonly associated to abrupt changes in the external and/or boundary conditions. 
The first type of adaptiveness is related to sustainability, i.e., to maintain a dynamic optimum in performance with due considerations to energy consumption, environmental impact, occupant comfort and well-being, which is referred to as climate adaptivity in here. The second, less common type of adaptiveness, is concerned with the response to - often rapidly changing loading conditions and consequently could be even related to disaster resilience.

The main concern is hence represented by the safety of the building towards different kind of exposures (i.e., wind, earthquake, explosions and fire) and how the load-bearing system can accommodate the effects of these hazards by changes in the structural characteristics. This is called structural adaptivity and is the main focus of this paper.

\section{Structural Adaptivity}

Structural adaptivity is beyond traditional structural engineering which typically deals with systems in static and dynamic equilibrium. In a structurally adaptivity system the equilibrium might change gradually involving large deformations and movements. The system is thus often a mechanism where the stiffness, the geometry or the external forces are controlled either 'manually' or 'automatically'. By 'manually' and 'automatically' here refers to what extent the structural response to the changes in the environment is regulated.

Sobek \& Teuffel (2001) describe adaptive structures as systems able to respond to changing external conditions through the manipulation of internal forces, deformations, or the external loads. This can be done in the following ways:

1) manipulation of the external loads, i.e., by adapting the shape of the structure (passive systems). In a facade, this could be rotation of elements to minimize wind exposure

2) manipulate structural parameters, i.e., to adapt material or element properties, such as stiffness, length or damping, to influence internal forces or deformations (active systems). In a facade, this could be adjusting prestress in response to the wind loading

3) a combination of (1) and (2), hence resulting in hybrid systems.

In general, according to Morales-Beltran \& Teuffel (2013), adaptive structures are those which can give a non-passive controlled response to (typically) earthquake and wind-induced motions. 'Non-passive' means that they rely on the use of external energy supply for the control action. Typically, they consist of sensors, control systems and actuators. Such systems can be then classified as active, hybrid and semi-active.

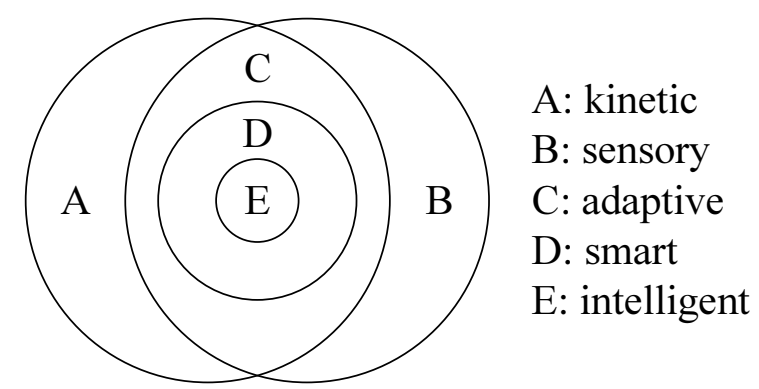

Fig. 1:Framework for the classification of adaptive structures, in accordance with (Morales-Beltran \& Teuffel, 2013)

\section{Classification of Structurally Adaptive Facades}

Based on Wada et al. (1990), also Morales-Beltran \& Teuffel (2013) proposed a general framework for categorizing adaptive structures, Fig. 1.

In the framework, kinetic structures are equipped with actuators capable of changing geometry or other structural characteristics. Sensory structures are equipped with a monitoring system to detect external/internal changes. In adaptive structures - based on the sensors input - a control system determines the actuators behavior. Smart and intelligent systems are considered as subgroups of adaptive structures.

Another, more specific classification on adaptive facades systems was proposed by Velasco et al. (2015). Accordingly, two aspects of the response are considered, namely movement and control, Fig. 2.

A similar but slightly different typology was suggested in the TU1403 Educational Pack in progress (http://www.tu1403.eu). An updated version is presented in Fig. 3.

The main aspects to consider in the proposed classification system are:

- system change

- system of activation and

- triggering event

System change describes how the adaptation in the structural system of the facade takes place. The most common form is by changing the overall geometry of the façade. This could be i.e., changing the position and/or orientation of some (or all) elements through translation and rotation (both in plane and/or out of plane). It could also involve changing the shape (distortion) and/or volume of the elements. Furthermore, any combination of these would be theoretically possible.

Besides changing the geometry, adjusting the overall stiffness is possible, thereby redistributing the internal forces. This could be done for example by changing the prestress in cable stays. 
The system of activation refers to how the response to the changes in the environment are initiated and controlled. This could be done at the material level, i.e., using materials which react to some kinds of exposures, hygroscopic materials responding to changes in humidity. These solutions typically do not require external input. Another common option is the application of mechanical actuators which typically require energy supply i.e., in form of electricity, hydraulic power or manual labor. The third option is the use of an inflatable system i.e., to change the shape and stiffness of the facade using air pressure.

One last major aspect to consider is related to the situation in which triggers response and leads to adaptive system change.
Two specific categories can be distinguished, namely associated to:

- ordinary/normal circumstances (i.e., self-weight, ordinary wind, temperature, humidity, etc.)

- extraordinary situation (i.e., natural hazards, accidents, intentional attacks, etc.)

In the former case, the adaptation is typically a slower process, the response is well controlled and proportional to the change to achieve an optimized performance. In the latter case, an abrupt event triggers an immediate response to mitigate devastating consequences due to the disastrous event.

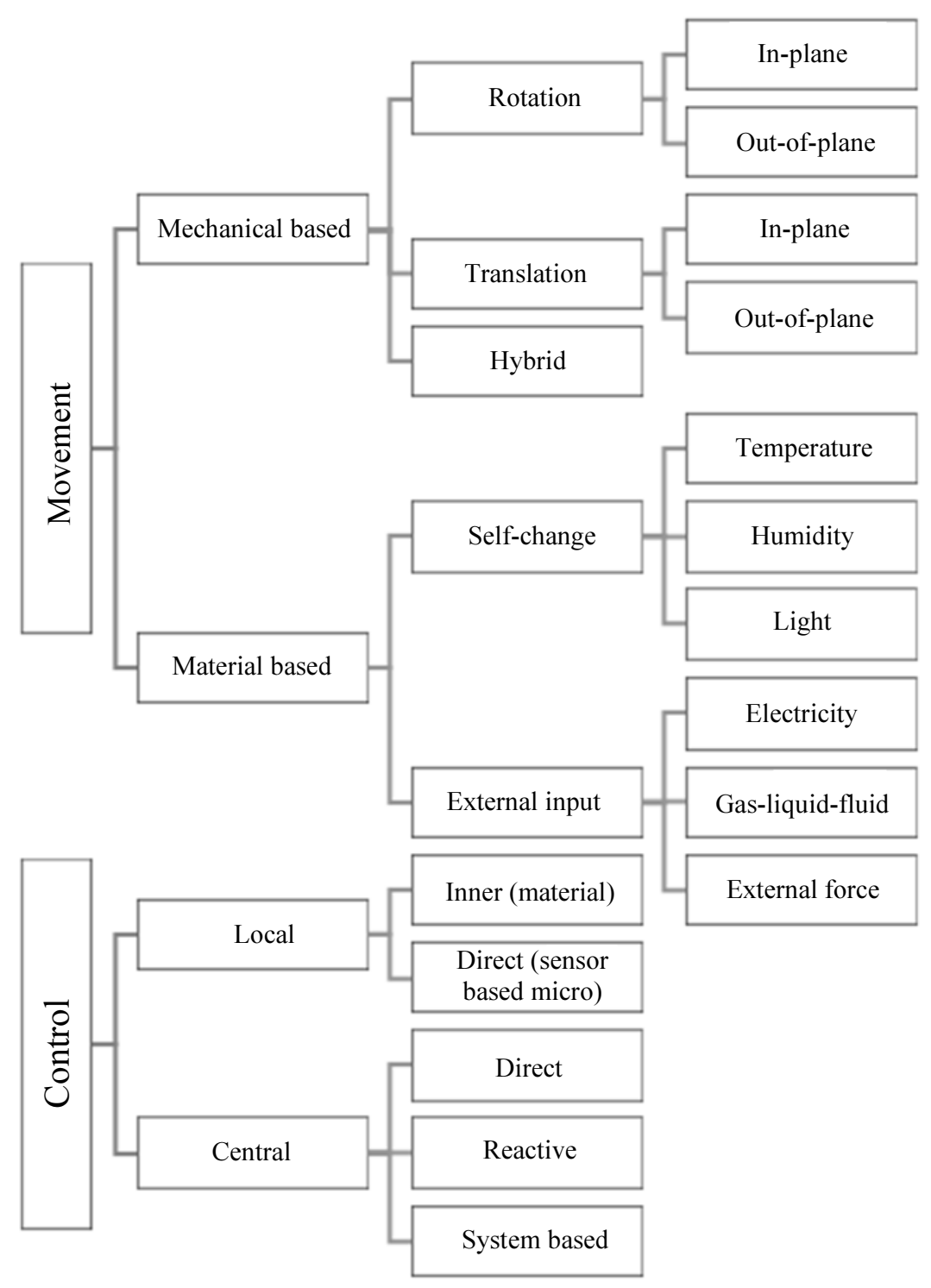

Fig. 2: Classification system of adaptive facades, as proposed in (Velasco et al., 2015) 


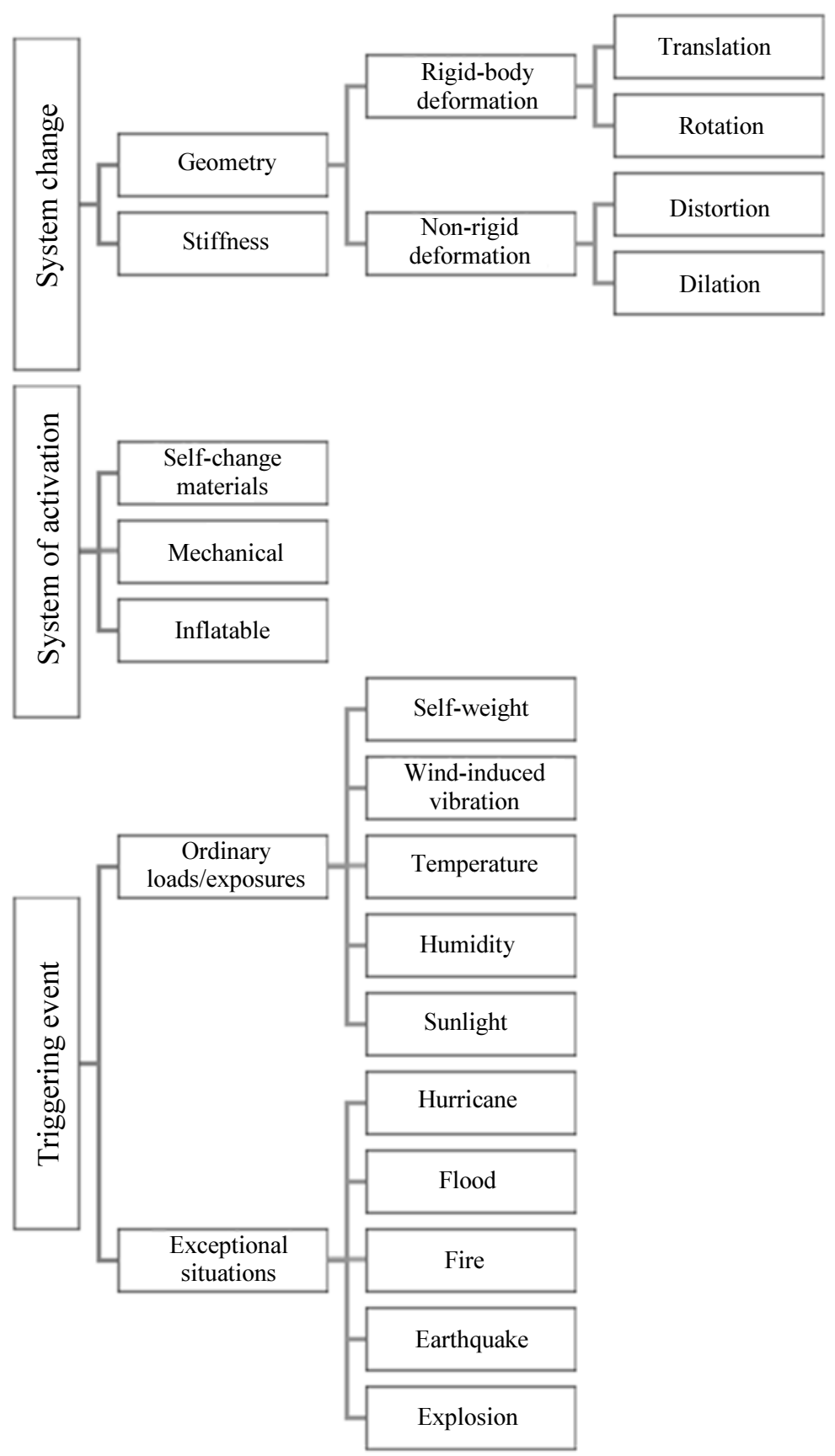

Fig. 3: Proposal of classification of adaptive facades, based on the Educational Pack in progress within the COST Action TU1403 (http://www.tu1403.eu)

\section{Structural Adaptivity Concepts}

The aforementioned description of structural adaptivity is rather generic, therefore a simple illustration of the concept is given in this section for the case study of a typical glass facade system. Concerning facades, the typical structural engineering concept is the 'materialization of lightness'. For example, in glass facade, the glass panes are suspended from a structural system which can assume a diversity of forms and that constitutes the main expression of the facade itself. These systems mostly rely on architectural grade steel elements, cable, rods and special stainless steel fittings that accommodate the glass panes deformations. In order to optimize the structural behavior of the facade, minimizing buckling problems, structural glass facades tend to make use of slender tensile elements, in detriment of compressed bulky components. 


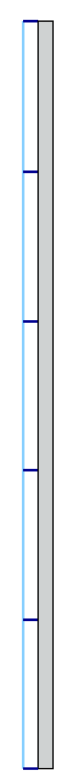

(a)

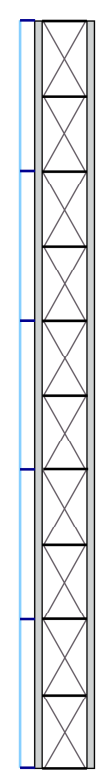

(b)

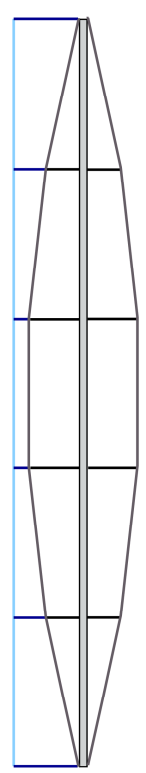

(c)



(d)

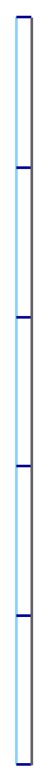

(e)

Fig. 4: Examples of systems for structural glass facades. (a) Mullion, (b) truss, (c) mast truss, (d) cable truss, (e) cable mullion

In Fig. 4, the most usual systems used in structural glass facades are represented, with increasing lightness from the conventional mullion system (a) to the cable mullion system (e). One can see that as the lightness of the system increases, the importance of cables and pre-stress in the behavior of the structural system also increases. Systems (a), (b) and (c) are usually called 'closed' systems, which are auto-equilibrated. Systems (d) and (e) are 'open' systems, that rely on the transmission of important forces to an exterior structural frame in order to maintain the overall stability.

The topic of structural adaptiveness in facade engineering is becoming increasingly important with the democratization of control systems, due to the development of new robust open-source microcontrollers and a multitude of sensors based in MicroElectro-Mechanical Systems, or MEMS. The concept of adaptivity in glass facades is, however, still very much limited to applications in the field of energy optimization and not structural optimization.

To control the displacements of a structural glass facade one can consider an active control approach (with feedback), in which the control variable of the system is a displacement of the facade, which is monitored in real time and compared with a pre-defined reference value. Through the implementation of an adequate control algorithm, one is able to minimize the error between the control variable and the reference value.

The high flexibility of structural glass facades can be used as an advantage regarding the implementation of adaptive features. In fact, even though their inherent flexibility is responsible for the high deflections shown by these structures, it also fosters the possibility to control these displacements with limited force inputs. One efficient way of introducing forces in these systems, taking into account the fact that most of them comprise pre-tensioned cables, is to use small electromechanical actuators in series with the cables, in order to modulate their tensions. As these cables usually work as antagonistic pairs the adaptive system is totally reversible and can adequately cope with the sign variations associated with wind loadings.

In Figures 5 and 6, the actuation principle for the proposed adaptive system, is illustrated. There, the control action compensates for the deflections introduced in structural glass facades associated with wind pressure and wind suction, respectively.

The proposed adaptive system is easy to implement in truss systems with diagonals built up of cables (Fig. 5 and 6b), mast truss systems (Fig. 5 and 6c) and cable trusses (Fig. 5 and 6d). In conventional mullion systems and cable mullion systems, however, it is not possible to make straightforward adaptations in the geometry of the structural system.

The main difference between the adaptive systems shown in Fig. 5 and 6 is mainly related to their structural redundancy and, therefore, resilience. By using several actuators spread throughout the structure - like in a truss system - it is possible use smaller actuators which, in case of individual failure, do not jeopardize the overall efficiency of the adaptive system. It is also preferable to use adaptive systems that are 'closed', in order to control the forces that have to be contained inside the adaptive structure. This is not possible in cable trusses, since the forces of the cables are transferred to an exterior structural frame. 


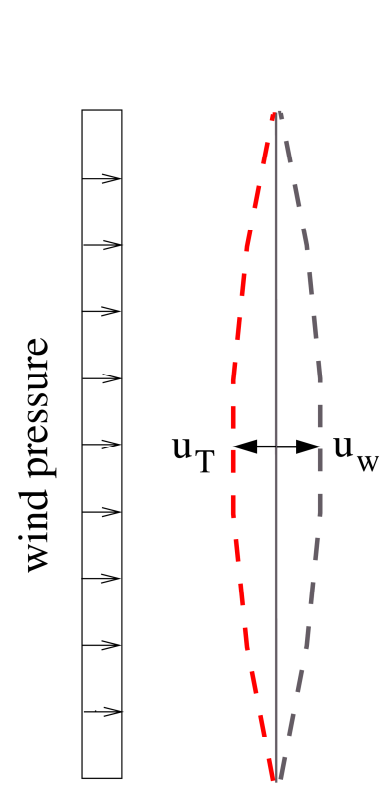

(a)

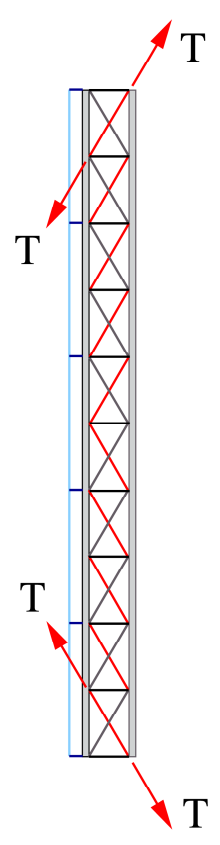

(b)

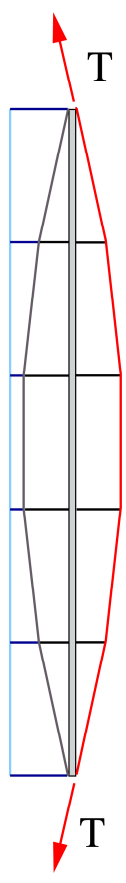

(c)

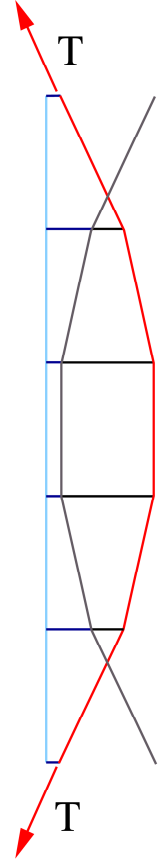

(d)

Fig. 5: Adaptive glass facades subjected to wind pressure. (a) Loading scheme, with (b) truss, (c) must truss, (d) cable truss systems

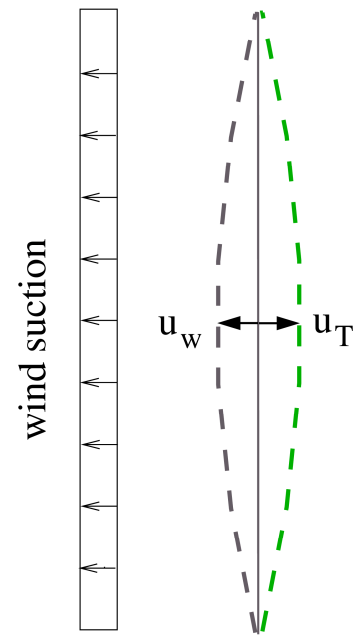

(a)



(b)



(c)

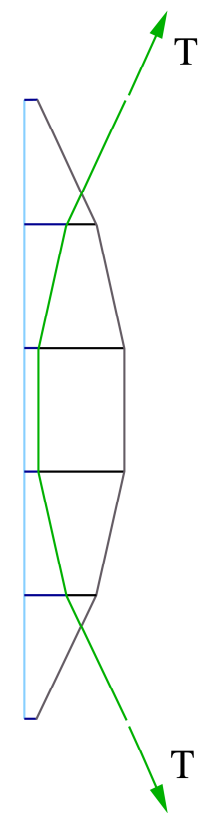

(d)

Fig. 6: Adaptive glass facades subjected to wind suction. (a) Loading scheme, with (b) truss, (c) must truss, (d) cable truss systems

\section{Examples of Adaptive Facades and Conceptual Installations}

As a first sub-task of the TG2.4 group, a brief overview of facade projects with structural adaptivity has been collected. An extensive list of case studies and available applications of adaptive facades is also a scheduled deliverable of WG2 members. This section, in particular, presents a selection of completed buildings and recent concepts from the ongoing TG2.4 activities, showing different forms of adaptivity.

As shown, most of the collected examples are related to specific (and mostly different) solutions having the main purpose to control solar glare and prevent 
overheating of buildings interiors. However, other concepts with more adaptive features are also presented. As a common rule, all the systems involve complex structural issues which have to be solved to make the adaptivity feasible.

\section{South Facade of the Arab World Institute, Paris, France (1987)}

Although the project was completed in 1987 it is still considered as one the most famous adaptive facades. The general concept and detailing finds its origin in oriental architecture (Fig. 7). The system is an extremely complex set of mobile diaphragms forms similar to the shutter mechanisms in a camera. The kinetics of the diaphragms is based on a local direct control system which involves series of photoelectric cells that are sensitive to light. When the photosensitive sensors (cells) receive less light, the diaphragms open. The automatic reverse mechanism closes the diaphragms under high solar gain. The south facade consists of 30,000 diaphragms made of steel. The main drawback of the system is its complexity and high number of mechanical devices which require constant maintenance.

\section{Kiefer Technic Showroom, Bad Gleichenberg, Austria (2009)}

The building has a simple dynamic facade composed of folded sunscreens involving perforated aluminum panels, see Figure 8 . The shutters operate automatically according to changing environmental conditions. When fully open, the daylight may enter the building as the enclosure is full transparent. The adaptive facade allows to control the solar glare by a fully automatic, electronic control system (with solar gain sensors) as well as by the users depending on their individual requirements in order to optimize the interior climate.

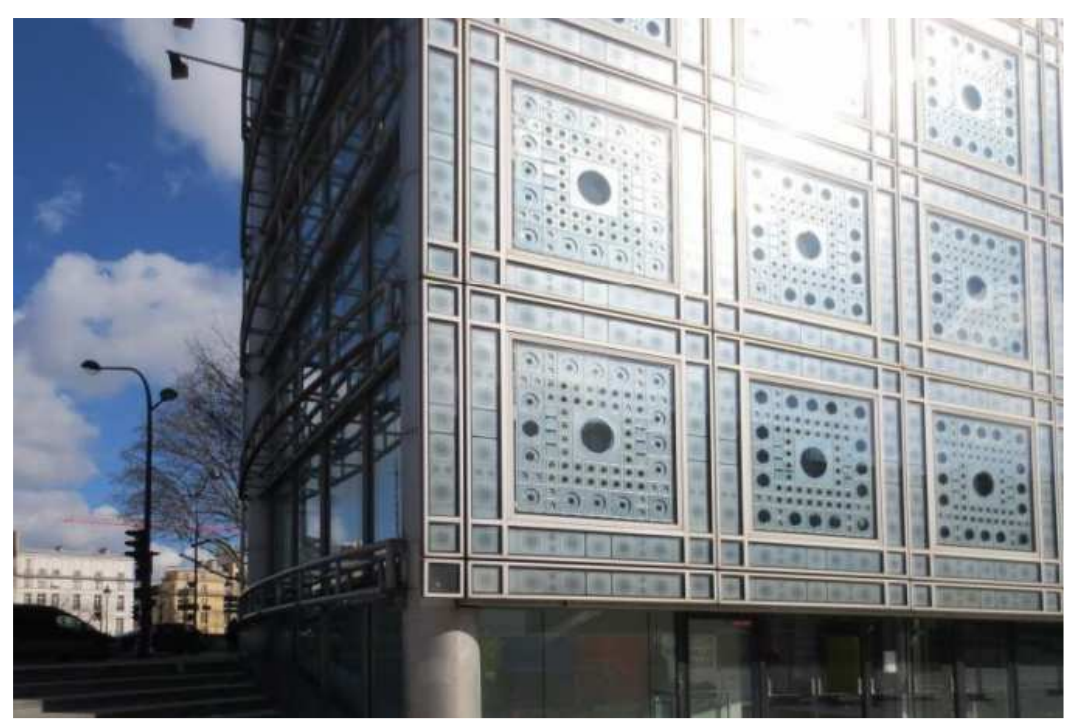

Fig. 7: South facade of the Arab World Institute, Paris, France (adapted from (Marysse, 2016))

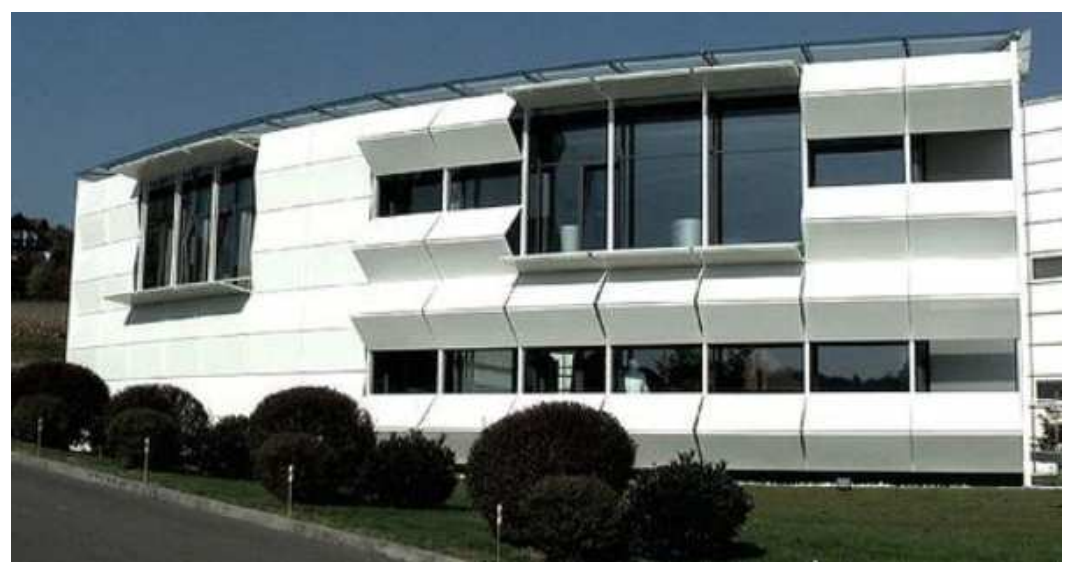

Fig. 8: Kiefer Technic Showroom, Bad Gleichenberg, Austria (adapted from (Marysse, 2016)) 


\section{Pola Ginza Building Facade, Tokyo, Japan (2009)}

The facade of the building is a double-skin enclosure that combines three functions: Thermal, optical and air flow. The facade is composed of individually controlled shutter mechanisms (Fig. 9). Each shutter is made of curved acrylic panels combined with LED lighting, which provide attractive appearance of the building at night. The dynamic facade maximizes the natural daylight entering the building, increases the solar gain in the winter and allows for natural ventilation by letting cooler air enter the building during night.

\section{CJ Cheiljedang R\&D Center, Seoul, South Korea (2012)}

The R\&D center consists of three drop-shaped towers with a central glass atrium. The project deploys external, kinetic shades to protect the interior spaces from excessive solar glare and reduce overheating (Fig. 10). The shades are perforated metal sheets installed on a set of pantographic actuators. When fully open the shades provide diffusive daylight into the building, while folded, the system allows direct, unobstructed sunlight enter the interior spaces. The segmented shades, installed around the perimeter of the building, can be activated independently as an automatic response to signal (exceeded predefined solar radiation or occupants/user input).

\section{One Ocean Pavilion, Yeosu, South Korea (2012)}

The pavilion, Fig. 11, was built for the EPOR 2012 event in Yeosu, as a response to the EXPO official theme which related to the ocean and coast. The building with biomorphic (fish-like) shape involves moveable Glass-Fiber Reinforced Polymers (GFRP) lamellas which by change of its form control the sunlight entering the building. The material and the geometry of the GFRP blades allow for repeated and reversible elastic deformations by lower and upper motors which generate rotation with screw spindles controlled by computerized motor. The system uses renewable energy as the power for the moving operation is powered by solar panels installed on the roof.

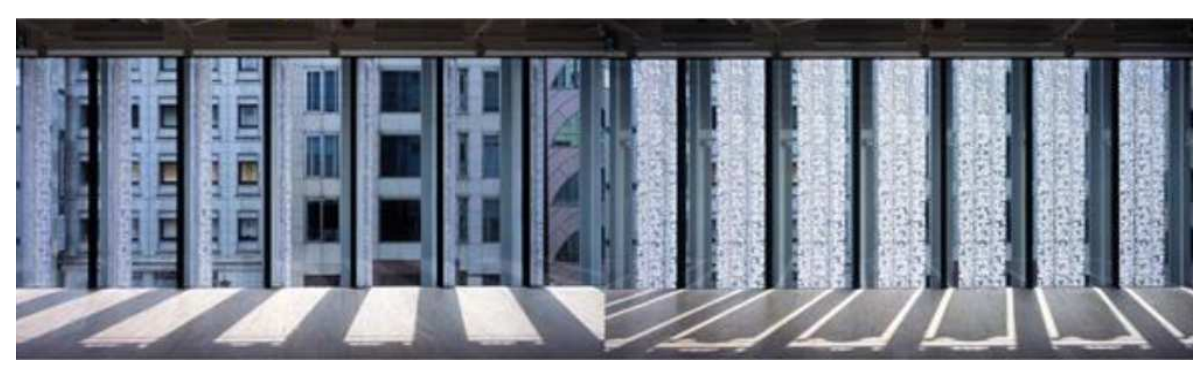

Fig. 9: Pola Ginza Building Facade, Tokyo, Japan (adapted from (Marysse, 2016))
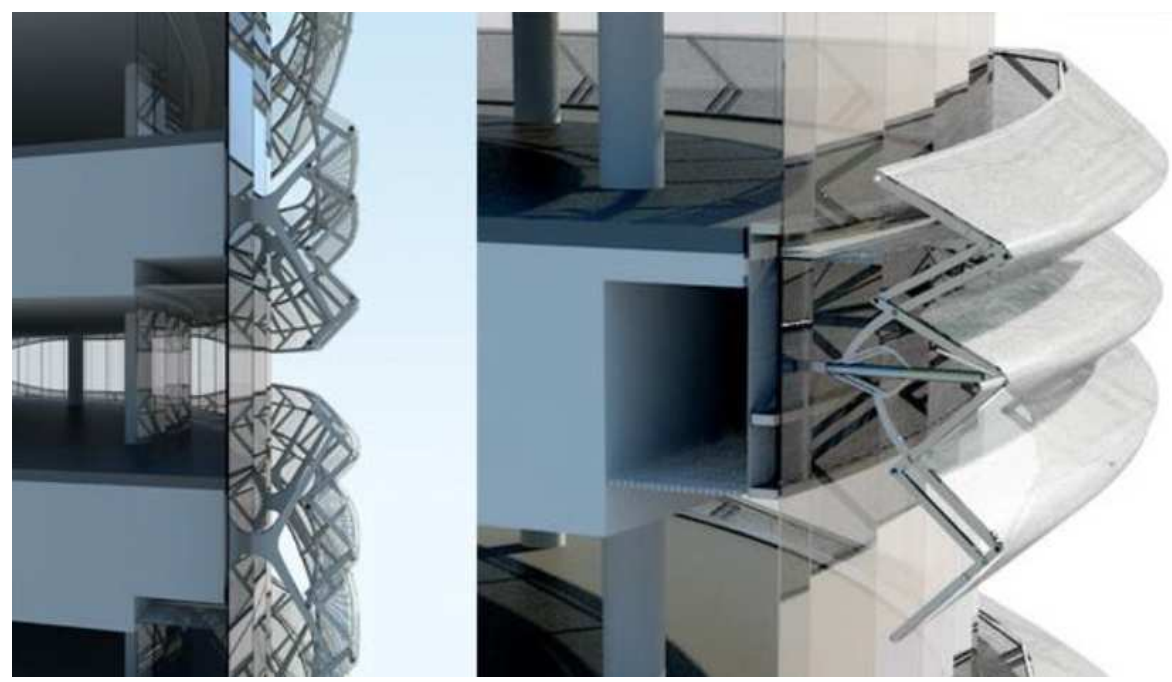

Fig. 10: CJ Cheiljedang R\&D center, Seoul, South Korea (adapted from (Asefi et al., 2017)) 


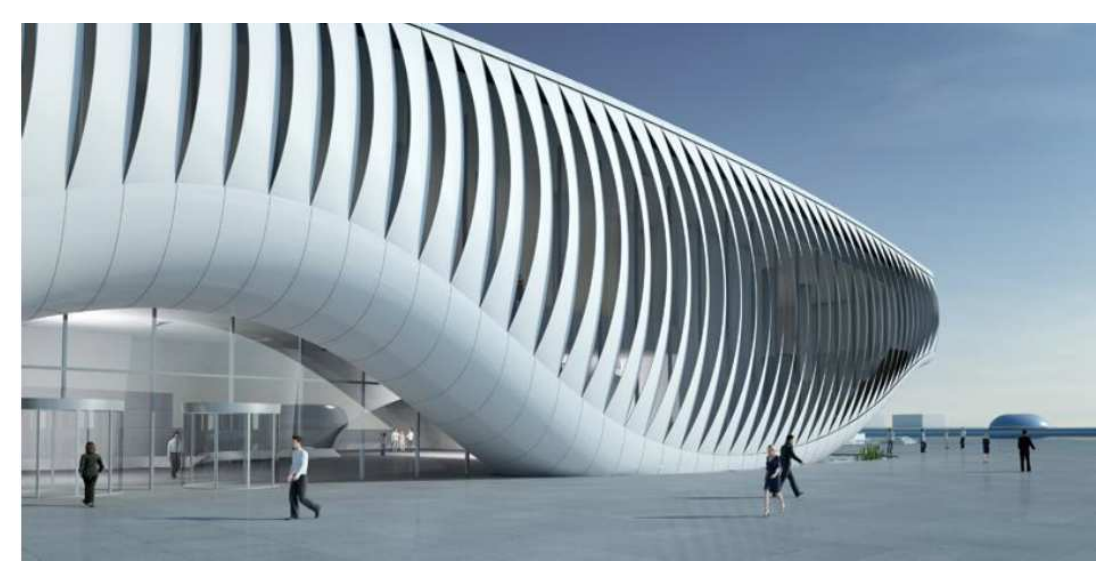

Fig. 11: One Ocean Pavilion, Yeosu, South Korea (adapted from (Marysse, 2016))



Fig. 12: Bloom Installation, San Diego, USA (adapted from (Marysse, 2016))

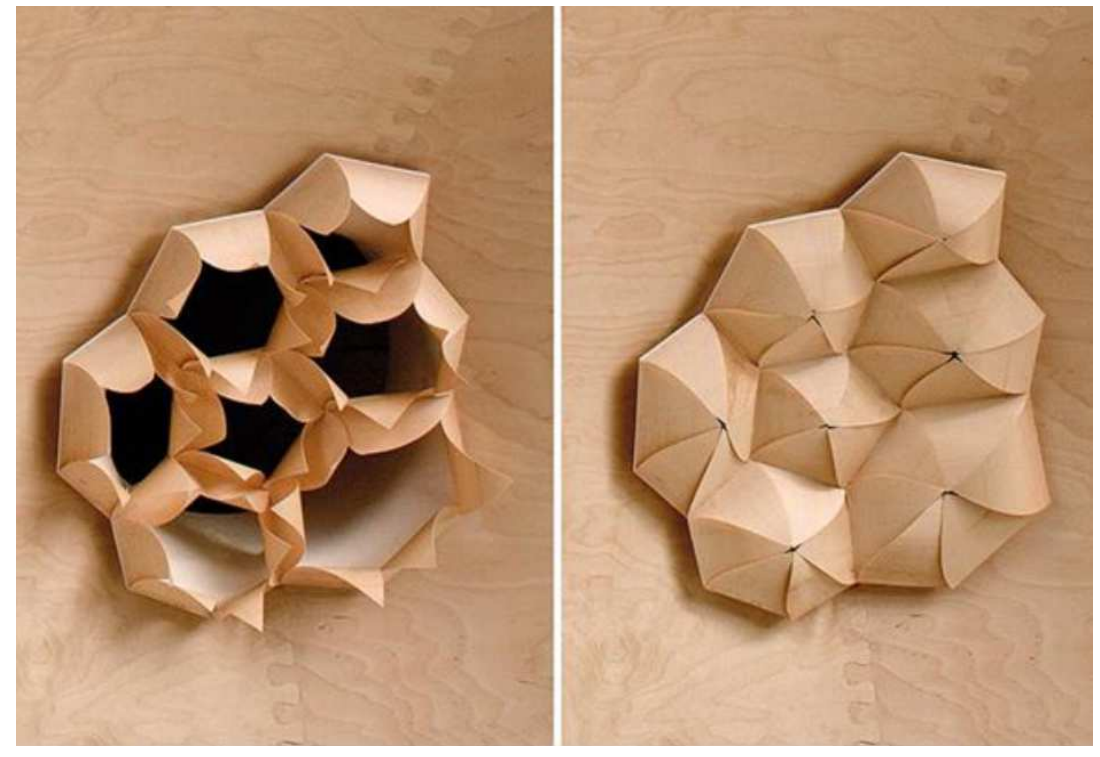

Fig. 13: HygroSkin-Meteorosensitive Pavilion, Orleans, France (adapted from (Marysse, 2016)) 


\section{Bloom Installation, San Diego, USA (2011)}

The installation is a concept that uses high-tech material science. It makes form of a shiny metal 'flower' of $6 \mathrm{~m}$ height, Fig. 12. It consists of thousand pieces of laser-cut, custom fabricated metal sheets made of thermal bi-metal plates. The plates are built of two laminated metal plates with different thermal expansion coefficients. This combination makes the 'flower' opening and closing according to the heat of the sun, deformation is caused by temperature changes and direct solar radiation. When the petals are heated by the sun, the panels open and provide efficient air flow. In such a design concept, there is no need for external power or mechanical parts as the kinetic deformation is a result of mechanical properties of the used materials.

\section{HygroSkin-Meteorosensitive Pavilion, Orleans,} France (2013)

The concept for adaptive behavior of the HygroSkin-Meteorosensitive Pavilion in Orleans is based on the responsive capacity of cells made of thin plywood sheets (Fig. 13).

The concept makes use of the material's sensitivity to the moisture content. In this sense, the skin interacts with the surrounding climate and it opens and closes (see a detail example in Fig. 13) in response to humidity changes. At the same time, the adaptive skin keeps the moisture content in equilibrium with the relative humidity of the environment. Similarly to the Bloom Installation design concept, the movement of the cells is based on material deformation properties and thus doesn't require external energy for activation.

\section{Structural Design of Adaptive Facades}

\section{Design method of adaptive structures and energy optimization}

In the design of conventional facade systems, the dimensioning procedure typically starts with designing for the ultimate limit state and follows by checking the serviceability requirements (i.e., deflections and vibrations). If the serviceability criteria are not fulfilled, typically the stiffness and/or the damping of the system is adjusted, often by increasing dimensions by adding more material. If the design of the facade is governed by varying load and especially by extraordinary loading situations e.g., strong wind storms or earthquakes, then the structure is often over-designed for most of the working life (Senatore et al., 2011). A main purpose of structural adaptivity is to optimize the structural response thereby saving material and energy consumption.

Senatore et al. (2011, 2013, 2018) developed a methodology for designing adaptive structures with optimized whole-life energy consumption considering both the embodied energy in the materials and an energy required for structural adaptation. In the presented cases, shape control is used to significantly increase stiffness (and diminish displacements) without prior information on the position, direction and magnitude of the external loads. However, the concept can be generalized for other kinds of structural adaptivity. The authors claim that for the studied structures designed with the method the adaptive solution can save up to $70 \%$ regarding the total energy when compared to optimized passive solutions, as illustrated in Figure 14. These promising results suggest that the same design concept could be used to develop structurally adaptive facade systems and further increasing the energy efficiency of the buildings.

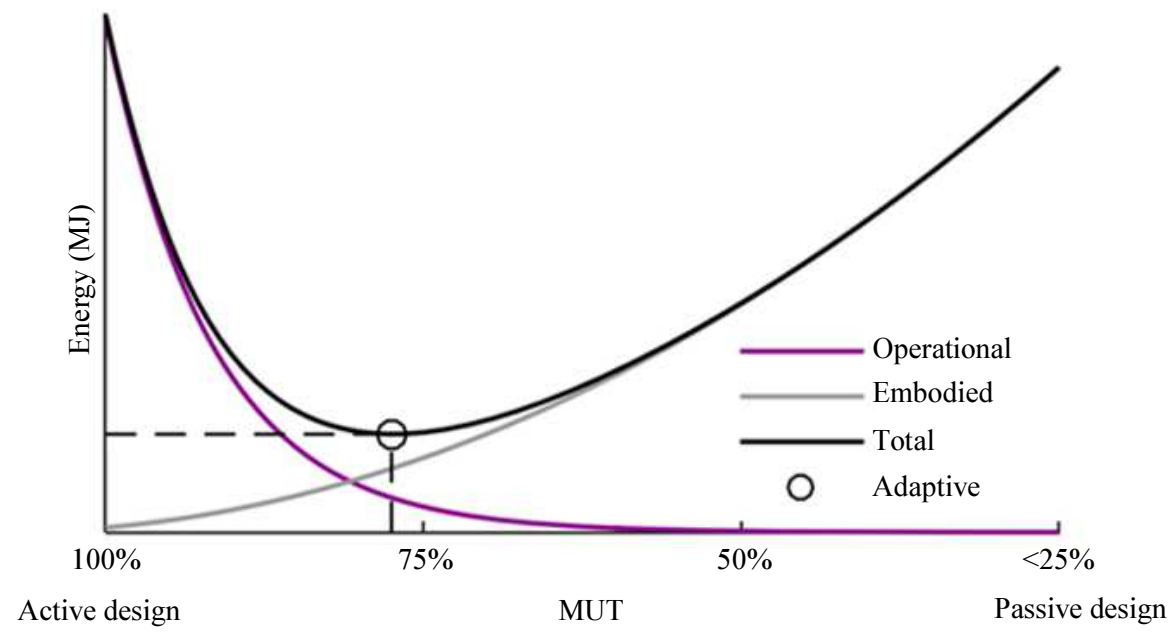

Fig. 14: Operational, embodied and total energy as a function of the MUT - material utilization factor (figure adapted from (Senatore et al., 2011)) 


\section{Standards and Guidelines}

Adaptive facades must meet a set of performance criteria as any other building envelopes and components. The criteria are specified at different levels: General harmonized conditions for construction products in Europe (EP, 2011), national building standards (EN 1990 (CEN, 2005)) and recommendations published by facade organizations (CWCT, 2018).

The most general regulatory framework for the performance of all construction products in Europe is the Construction Products Regulation (EP, 2011). It specifies five basic requirements for construction works: Mechanical resistance and stability, safety in case of fire, hygiene, health and the environment, safety and accessibility in use, protection against noise, energy economy and heat retention and sustainable use of natural resources.

EN 1990 (CEN, 2005) defines requirements for safety, serviceability and durability of structures. It describes the basis for their design and verification and provides guidelines for related aspects of structural reliability. EN 1990 should be used in conjunction with other standards including geotechnical works, fire design, accidental situations (earthquakes) and execution.

The Centre for Window and Cladding Technology (CWCT) is an example of industry funded centre providing more specific performance criteria for facades. It publishes both standards and guidelines developed together by leading architects, consultants, contractors and manufacturers.

\section{Structural Requirements}

Building envelopes are commonly required to resist self-weight, environmental actions (i.e., thermal effects and wind load), natural (i.e., earthquake) and man-made (i.e., impact and explosion) hazards. Moreover, structural design of adaptive facades has to solve structural consequences due to adaptive/movable systems, together with structural and cost consequences for the supporting substructures.

Wind loading, for example, is highly dynamic phenomenon and therefore a very interesting driver for adaptive architecture, see for example (Teuffel, 2011). Adaptive elements on facades influence flow fields along the building envelopes and thus they can geometrically optimise building skins as wind responsive. However, there is a need for a sufficient strength and stiffness of adaptive facades components, supporting substructures and connections. Adaptive facades are in fact anchored via substructures to the buildings, therefore it is essential to evaluate whether these structural systems are capable of bearing possible additional loads due to adaptive mechanisms.

Actuators of adaptive facades can also significantly affect dead loads to account for design: mechanically driven kinematic systems, most probably, would lead to heavy complex constructional components, while lightweight shape morphing elements could be constructed with smart materials (Lignarolo et al., 2011).

\section{Special Considerations for Adaptivity}

Current recommendations and regulations of standards (for traditional, static facades) naturally lack of specific rules, recommendations and guidelines for design and testing of adaptive facades. This is due to their specific features involving a variety of mechanisms, such as sensor and actuator systems. As these are intended to operate during the entire life time of a facade, special attention should be paid to fatigue resistance and structural integrity of the whole system. Moreover, a back-up system must be provided as a response to a possible failure of control systems or any other component of a given adaptive facade. A special procedure must be also provided for accidental events, such as lack of power, system malfunction, acts of vandalism, etc.

\section{Experimental Testing}

\section{Relevant Testing Standards}

Within the European Economic area (EEA), all products with a CE marking have a proved conformity with the relevant EU standards. Moreover, this allows free movement and sale of those products within the EEA, regardless of where manufactured. The most relevant standard for facades is the EN 13830 'Curtain walling - Product standard'. Another relevant document is ETAG 034 'Guideline for European Technical Approval of Kits for External Wall Claddings' issued by European Organisation for Technical Approvals (EOTA). ETAG documents are issued and applied when product standards do not cover some specific areas.

The EN 13830 specifies different sub tests and test procedures for a facade performance classification by experimental testing. The main test procedure according to EN 13830 includes air permeability, watertightness, wind load serviceability, air permeability II, watertightness II and wind load resistance. This procedure has to be performed in one run for the classification. A main idea of this procedure is that the facade performance is not just a laboratory or theoretical value and the whole facade is in a similar condition as it is in real. Moreover, the real scale test element often includes usual installation tolerances.

The ETAG 034 states requirements accompanied by corresponding test methods in fields of mechanical resistance and stability, safety in case of fire, hygiene, health and environment, safety in use, protection against noise, energy economy and heat retention, aspects of durability and serviceability. 
It is certainly true that these standards and procedures are developed for traditional static facades. On the other hand, the development of standard testing procedures for an adaptive, moveable, dynamic, kinetic, responsive, switchable, interactive, etc. facade is neither feasible nor promising. Therefore, the applicability of standard testing and the considerable boundary condition has to be examined case-by-case. In addition, negative interaction of adaptive behavior and performance criteria must be considered. For example, if a facade changes the form due to wind load, it is possible that joints could offer lower air permeability or water-tightness, hence requiring careful attention for assessment purposes.

\section{Special Considerations for Structural Adaptivity}

Adaptive facades are not standard assemblies and their performance is hardly tangible by out of-the-box testing procedures. On the other hand, there are established tests to claim compliance with essential safety requirements. Therefore, manufacturers and customers have to come to an agreement how to declare the adaptive facade performance, which standards should be applied or adjusted. In some cases, the development of additional and unique tests is a major part in adaptive facade design.

Thinking about out-of-plane movement of adaptive facades, there could be joints that allow water to penetrate without impact to water-tightness; However, water could remain and enclosed when the facade moves back its original shape. The movable parts of adaptive facades can also affect their lifetime with regard to the possible cyclic load and fatigue of individual parts. Experimental verification of the durability and reliability will always require individually designed test procedures. Also, under wind loads, moving parts can cause changes in airflow, especially in the case of highrise buildings which may require subsequent verification of the building model behavior in the wind tunnel. Marutaa et al. (1998) reported experimental data for a model in scale $1 / 300$ of the high-rise house square section and $75 \mathrm{~m}$ high that wind pressures are significantly affected by the surface roughness, particularly near the leading edge of the side wall on which local severe peak pressures decrease with increasing roughness. The increase of roughness reduces the development of conical vortices formed at the lower and higher zone of buildings.

Regarding existing standards and test procedures, the experimental testing of adaptive facades could be a challenging task. There are probably various options to customize test facilities to the adaptive behavior. Therefore, a careful preparation and a lot of 'what if' thinking is the key factor for satisfactory adaptive facade tests.

\section{Structural Numerical Modelling of Adaptive Facades}

\section{Challenges in Numerical Modelling}

As discussed in (Kozłowski et al., 2018), numerical modelling has an important role in designing and developing adaptive facade systems. From a structural perspective Finite Element (FE) simulations can be extremely beneficial by providing a robust and reliable tool for both supporting and sometimes even replacing testing of components, sub-systems or entire systems. Since full scale testing can be both time consuming and costly, advanced modelling can realize significant savings and enable project completion on time.

As far as the reliability of FE estimations is strictly related to input parameters and modelling assumptions, the complexity of the structural system to analyze its strictly related to the increasing number of critical aspects to properly assess at the FE modelling stage. So far, several researchers focused on the FE analysis of traditional curtain wall facades or cable-supported facade systems, under ordinary as well as exceptional loads. An extended state-of-the-art review can be found in (Bedon et al., 2018d).

There, depending on the study goal, careful consideration has been spent for the materials characterization and/or system mechanisms, especially in presence of specific boundary conditions (see for example Fig. 15, with evidence of a point-supported glazing facade with mechanical fasteners and enhanced Viscoelastic (VE) dampers). Research investigations have been hence focused on blast effects, seismic loading conditions, connection components (see (Bedon et al., 2018d) for specific literature references).

The complexity of the numerical simulations is much higher when considering adaptive facade systems, where a multitude of aspects should be properly taken into account. Generally speaking, such a complexity and uncertainty can originate from several key aspects, including material properties as well as kinematics for these complex assemblies. Actually, most of the numerical studies related to adaptive systems are in fact focused on energy and thermal efficiency considerations, while the current lack of modelling recommendations and guidelines often represents the major obstacle for the reliable structural assessment of adaptive systems via $\mathrm{FE}$ tools.

In (Lienhard et al., 2011a, 2011b), for example, the load bearing capacity of the kinetic facade modular units composing the One Ocean thematic Expo Pavilion in South Korea (i.e., Fig. 11) has been partly numerically assessed, giving evidence of the critical role of mechanical joints under bending and torsion, as well as on the optimal design of each adaptive component to mitigate stress peaks. 

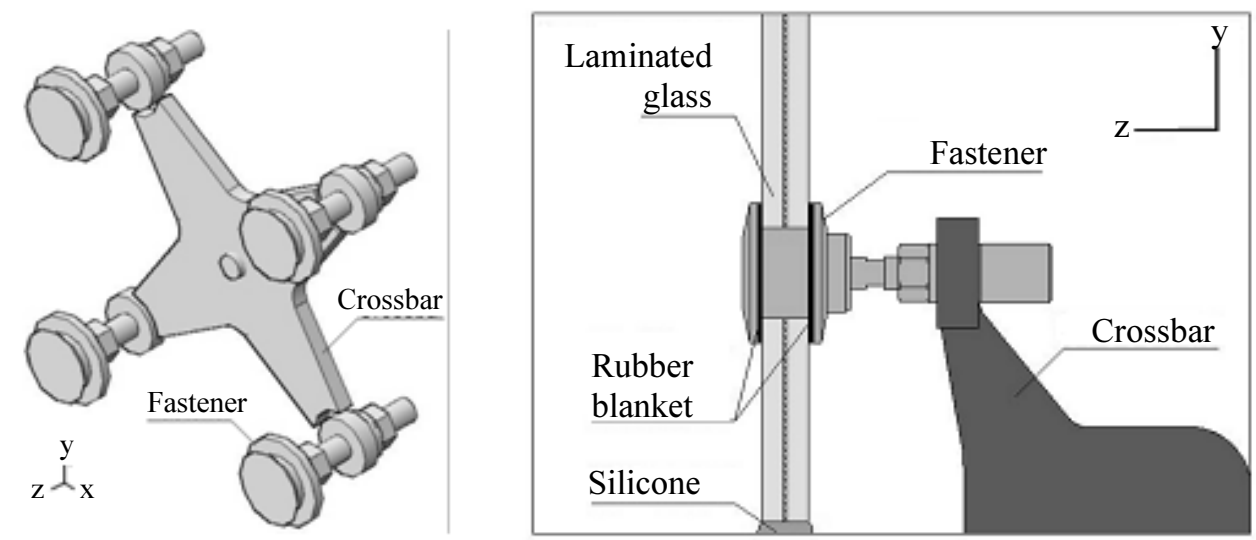

(a)

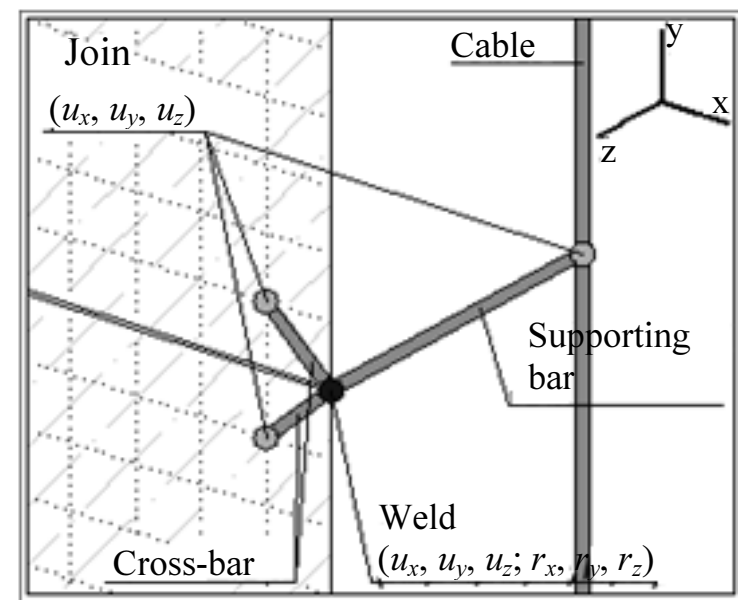

(b)

Fig. 15: Numerical modelling of a cable-supported glass facade: (a) typical mechanical point-supports and (b) corresponding FE assembly, including viscoelastic (VE) dampers for impact protection. Figures reproduced from (Amadio \& Bedon, 2012) with permission from Elsevier (license n.4360650481549, Copyright Agreement: June 2018)

\section{Some Preliminary Recommendations}

The FE analysis of an adaptive facade differs significantly from that of a traditional one, since the analysis should properly define some key aspects which are representative for various key input parameters. On the other hand, several other questions should be considered, including:

- material properties. The most appropriate constitutive law (i.e., linear elastic, damage model, degradation of mechanical properties under cyclic loads and/or time/temperature variations, etc) should be preliminary selected, depending on the expected adaptive behaviour. In this regard, an attempt towards a possible FE modelling standardization for glass facades and windows under explosions can be found in (Larcher et al., 2016)

- mechanical interaction between the facade components: Connections and joints should be properly reproduced (even in a simplified/ideal way), so to allow a reliable description of the actual structural response of each facade component, as well as the reciprocal mechanical interaction between components (as parts of the full adaptive assembly object of analysis)

- loading condition: Even in presence of ordinary design loads only, adaptive facades are first associated to cyclic and/or kinematic behaviors. In this regard, the FE model should be able to actually reproduce (at the component and/or assembly level) such a kind of performance (i.e., including possible fatigue effects and degradation of input properties)

- boundaries: Being generally described via ideal restraints, special care in FE modelling of adaptive facades should be spent for restraints and supports. In most of the cases, such structural details can in fact be responsible of possible premature failure mechanisms (i.e., due to local peaks of stresses, etc.), as well as implicitly related to additional 
eccentricities to properly account for structural assessment purposes

- adaptive facades under extreme events: FE simulations can provide useful support for the structural assessment of adaptive facades under extreme loading conditions, including accidents as well as natural hazards. In this case, the FE modelling complexity further increases, since strong efforts should be spent both on the adaptive facade side (i.e., the points above) as well as on the loading description side (i.e., equivalent static loads, etc.), hence requiring a preliminary selection of the solving strategy and related modelling assumptions (i.e., equivalent static simulations, non-linear dynamic analyses, etc.)

\section{Conclusion}

Adaptive facade systems are getting more and more common in the design of modern buildings. Due to their adaptive behaviour, in response to the changes in their environment, special requirements might be needed to ensure appropriate safety levels for the building occupants. In this study, a brief overview of major structural requirements for adaptive facades has been reported, together with a possible classification of structural adaptivity issues.

Differing from traditional systems, the multiple ways the adaptive structures can interact with the environment and change intrinsic mechanical characteristics need to be properly taken into account, both for experimental testing and numerical modelling.

In addition to all the possible benefits, the design of an adaptive facade is still a challenging task. The engineer has to keep in mind that current standards and procedures cannot always be applied. In addition, further thoughts on disaster management - such as functional or energy supply failure - must be made and integrated to the planning process. Nevertheless, a well-designed adaptive facade provides opportunities to fulfill the European energy targets. Not only by obvious energy savings in climate responsive functions. In addition, embodied energy can be optimized due to multi-use of materials or components by the adaptive functionality.

\section{Acknowledgement}

This paper collects some outcomes of the 'Structural' Task Group (TG2.4) within the ongoing European COST Action TU1403 'Adaptive Facades Network' (20142018, http://www.tu1403.eu).

In this regard, COST is gratefully acknowledged for providing excellent research networking between the involved authors, as well as with international experts.

All the Network members that supported the TG2.4 activities are finally acknowledged for their cooperation.

\section{Funding Information}

No funding was received for the preparation of this manuscript.

\section{Author's Contributions}

This paper results from an active support and networking from all the involved authors.

\section{Ethics}

The authors declare that there are no conflicts of interest.

\section{References}

Aelenei, D., L. Aelenei and C. Pacheco Vieira, 2016. Adaptive façade: Concept, applications, research questions. Energy Proc., 91: 269-275.

DOI: 10.1016/j.egypro.2016.06.218

Amadio, C. and C. Bedon, 2012. Viscoelastic spider connectors for the mitigation of cable-supported facades subjected to air blast loading. Eng. Structures, 42: 190-200.

DOI: 10.1016/j.engstruct.2012.04.023

Asefi, M., M. Mitton and S. Currie, 2017. A new foldable kinetic architectural system: Through an evaluative approach of built examples, case studies: Resonant chamber, cheiljedang research center, Madina Shadi project. Armanshahr Architecture Urban Dev., 10: 1-12.

Attia, S., 2017. Evaluation of adaptive facades: The case study of Al Bahr Towers in the UAE. QScience Connect. DOI: 10.5339/connect.2017.qgbc.6

Attia, S., P. Eleftheriou, F. Xeni, R. Morlot, C. Ménézo et al., 2017. Overview and future challenges of nearly Zero Energy Buildings (nZEB) design in Southern Europe. Energy Build., 155: 439-458. DOI: 10.1016/j.enbuild.2017.09.043

Balocco, C. and G. Petrone, 2017. Numerical modelling for the thermal performance assessment of a semiopaque facade with a multilayer of nano-structured and phase change materials. Buildings, 7: 90-90. DOI: 10.3390/buildings7040090

Barozzi, M., J. Lienhard, A. Zanelli and C. Monticelli, 2016. The sustainability of adaptive envelopes: Developments of kinetic architecture. Proc. Eng., 155: 275-284. DOI: 10.1016/j.proeng.2016.08.029

Bedon, C. and M. Santarsiero, 2018a. Transparency in structural glass systems via mechanical, adhesive and laminated connections - existing research and developments. Adv. Eng. Mater., 20(5), Article ID: 1700815. DOI: 10.1002/adem.201700815 
Bedon, C. and M. Santarsiero, 2018b. Laminated glass beams with thick embedded connections-numerical analysis of full-scale specimens during cracking regime. Comp. Structures, 195: 308-324. DOI: $10.1016 /$ j.compstruct.2018.04.083

Bedon, C., 2017. Structural glass systems under fire: Overview of design issues, experimental research and developments. Adv. Civil Eng., 2017, Article ID: 2120570, pp: 18. DOI: 10.1155/2017/2120570

Bedon, C., F. Santos, C. Amadio and C. Cismasiu, 2015. Passive and active control systems for adaptive glazing facades and envelopes. Proceedings of the 'Adaptive Facade Network - Europe' Industry Workshop. Luible, Overend, Aelenei, Knaack and Perino and Wellershoff (Eds.), TU Delft Open, ISBN-13: 978-94-6186-581-6, pp: 31-31.

Bedon, C., F. Favoino, C. Pascual Agullo, A. LunaNavarro and M. Overend, 2017a. Thermal and structural assessment of novel GFRP-glass sandwich facade components via numerical simulations. Proceedings of NE-XT facades - COST Action TU1403 Adaptive Facades Network - Mid-Term Conference, Technical University of Munich, Germany. Molter, Mungenast, Banozic, Englhardt and Klein (Eds.).

Bedon, C., R. Kalamar and M. Eliášová, 2017b. Glass columns under impact - experimental and numerical analyses. Key Eng. Mater., 755: 82-89.

DOI: $10.4028 /$ www.scientific.net/KEM.755.82

Bedon, C., R. Kalamar and M. Eliášová, 2017c. Low velocity impact performance investigation on square hollow glass columns via full-scale experiments and Finite Element analyses. Comp. Structures, 182: 311-325. DOI: 10.1016/j.compstruct.2017.09.055

Bedon, C., M. Kozłowski, D. Honfi, K. Machalická, M. Eliášová et al., 2017d. Evaluating the structural performance of adaptive facades: General rules and guidelines for classification, experimental testing and numerical modeling. Proceedings of NE-XT Facades - COST Action TU1403 Adaptive Facades Network - Mid-Term Conference, Technical University of Munich, Germany. Molter, Mungenast, Banozic, Englhardt and Klein (Eds.).

Bedon, C., D. Honfi and M. Kozłowski, 2018a. Numerical modelling of structural glass elements under thermal exposure. Proceedings of the 3rd International Electronic Conference on Materials Sciences, MDPI AG. DOI: 10.3390/ecms2018-05241

Bedon, C., K. Machalická, M. Eliášová and M. Vokáč, 2018b. Numerical modelling of adhesive connections including cohesive damage. Proceedings of Challenging Glass 6 - Conference on Architectural and Structural Applications of Glass, TU Delft, The Netherlands, pp: 309-320. Luter, Bos, Belis, Veer Nijsse (Eds.). DOI: 10.7480/cgc.6.2155
Bedon, C., C. Pascual Agullo, A. Luna-Navarro, M. Overend and F. Favoino, 2018c. Thermomechanical investigation of novel GFRP-glass sandwich facade components. Proceedings of Challenging Glass 6 - Conference on Architectural and Structural Applications of Glass, TU Delft, The Netherlands, pp: 501-512. Luter, Bos, Belis, Veer Nijsse (Eds.), DOI: 10.7480/cgc.6.2172

Bedon, C., X. Zhang, F. Santos, D. Honfi, M. Kozłowski et al., 2018d. Performance of structural glass facades under extreme loads - Design methods, existing research, current issues and trends. Construct. Build. Mater., 163: 921-937.

DOI: $10.1016 /$ j.conbuildmat.2017.12.153

CEN, 2005. EN 1990 Eurocode - basis of structural design. European Committee for Standardization, Geneva.

COST Action TU1403, 2014. Memorandum of understanding. http://www.cost.eu/COST Actions/tud/TU1403

Cruz, P.J.S., P.L. Carvalho and F.A. Veer, 2015. Folded reinforced glass connection systems. Proceedings of the 'Adaptive Facade Network - Europe' Industry Workshop. Luible, Overend, Aelenei, Knaack and Perino and Wellershoff (Eds.), TU Delft Open, ISBN-13: 978-94-6186-581-6, pp: 67-67,

CWCT, 2018. Centre for Window and Cladding Technology, 2018. Intelligent Facades, http://www.cwct.co.uk/ibcwindow/adaptive/adapt.html

EC, 2010. Energy 2020 - A strategy for competitive, sustainable and secure energy. European Commission.

EC, 2012. Energy roadmap 2050. European Commission.

https://ec.europa.eu/energy/sites/ener/files/document s/2012_energy_roadmap_2050_en_0.pdf

European Parliament, 2011. Regulation (EU) No. $305 / 2011$ of the European parliament and of the council of 9 March 2011 laying down harmonised conditions for the marketing of construction products and repealing Council Directive 89/106/EEC. Official J. European Union, 88: 5-43

Favoino, F., M. Overend and Q. Jin, 2015. The optimal thermo-optical properties and energy saving potential of adaptive glazing technologies. Applied Energy, 156: 1-15.

DOI: $10.1016 /$ j.apenergy.2015.05.065

Firmo, F., S. Jordão, L. Costa-Neves and C. Bedon, 2016. The effect of adhesive joints on the performance of hybrid steel-glass beams - An analytical and experimental study. Proceedings of Challenging Glass 5 - Conference on Architectural and Structural Applications of Glas, Ghent University, Belgium, pp: 171-185. Belis, Bos and Louter (Eds), ISBN-10: 978-90-825-2680-6 DOI: $10.7480 / \operatorname{cgc} .5$ 
Hasselaar, B. and R. Looman, 2007. The climate adaptive skin, the integral solution to the conflict between comfort and energy performance. Proceedings of the CIB World Building Congress, pp: 1115-1125.

Jordão, S., L. Simões da Silva and A. Santiago, 2015. Ongoing research on structural glass. Proceedings of the 'Adaptive Facade Network - Europe' Industry Workshop. Luible, Overend, Aelenei, Knaack and Perino and Wellershoff (Eds.), TU Delft Open, ISBN-13: 978-94-6186-581-6, pp: 40-40.

Kalamar, R., C. Bedon and M. Eliášová, 2017. Assessing the structural behaviour of square hollow glass columns subjected to combined compressive and impact loads via full-scale experiments. Eng. Structures, 143: 127-140.

DOI: $10.1016 /$ j.engstruct.2017.04.016

Kim, J., 2013. Adaptive facade design for the daylighting performance in an office building: The investigation of an opening design strategy with cellular automata. Int. J. Low-Carbon Technol., 10: 313-320. DOI: $10.1093 / \mathrm{ijlct} / \mathrm{ctt} 015$

Kozłowski, M., C. Bedon, K. Machalická, T. Wüest and D. Honfi, 2018. Structural aspects of adaptive facades. Proceedings of the 5th International Academic Conference on Places and Technologies, University of Belgrade, Serbia, pp: 493-499.

Kozłowski, M., E. Serrano and M. Dorn, 2015. Timber Glass Composites. Proceedings of the 'Adaptive Facade Network - Europe' Industry Workshop. Luible, Overend, Aelenei, Knaack and Perino and Wellershoff (Eds.), TU Delft Open, ISBN-13: 97894-6186-581-6, pp: 62-62.

Larcher, M., M. Arrigoni, C. Bedon, A. van Doormaal, C. Haberacker et al., 2016. Design of blast-loaded glazing windows and facades: A review of essential requirements towards standardization. Adv. Civil Eng., 2016, Article ID: 2604232, pp: 14. DOI: $10.1155 / 2016 / 2604232$

Lienhard, J., S. Schleicher, A. Poppinga, T. Masselter and M. Milwich, 2011a. Flectofin: A hingeless flapping mechanism inspired by nature. Project Brochure, www.itke.uni-stuttgart.de

Lienhard, J., S. Schleicher, S. Poppinga, T. Masselter, M. Milwich et al., 2011b. Flectofin: A hingeless flapping mechanism inspired by nature. Bioinspir Biomim, 2011: 045001-045001. DOI: $10.1088 / 1748-3182 / 6 / 4 / 045001$

Lignarolo. L.E.M., C.M.J.L. Lelieveld and P. Teuffel, 2011. Shape morphing wind-responsive facade system realized with smart materials. Proceedings of Adaptive Architecture: An International Conference (London, UK, March 3-5, 2011), pp: 12.
Loonen, R.C.G.M., M. Trčka, D. Cóstola and J.L.M. Hensen, 2013. Climate adaptive building shells: State-of-the-art and future challenges. Renewable Sustainable Energy Rev., 25: 483-493.

DOI: $10.1016 /$ j.rser.2013.04.016

Machalická, K. and M. Eliášová, 2015. Advanced analysis of glued connections for facades systems Innovative solution for exterior elements connections of adaptive facades. Proceedings of the 'Adaptive Facade Network - Europe' Industry Workshop. Luible, Overend, Aelenei, Knaack and Perino and Wellershoff (Eds.), TU Delft Open, ISBN-13: 978-94-6186-581-6, pp: 28-28.

Machalická, K., I. Pravdová and M. Eliášová, 2015. Shear adhesive connections for glass structures. Mater. Sci. Eng., 96: 012069-012069. DOI: 10.1088/1757-899X/96/1/012069

Machalická, K., M. Eliášová and M. Vokáč, 2017a. Structural glued connections with different metal substrates. CE/Papers, Special Issue: Proceedings of Eurosteel, 1: 679-684. DOI: 10.1002/cepa.106

Machalická, K., M. Vokáč and M. Eliášová, 2017 b. Experimental and numerical analysis of acrylate adhesive joints. Proceedings of the 2nd International Conference on Engineering Sciences and Technologies, Technical University of Košice, Slovak Republic, ISBN-13: 978-80-553-2564-4

Machalická, K., M. Vokáč and M. Eliášová, 2017c. Effect of laboratory ageing on structural adhesive joints with metal substrates. Proceedings of the 7 th International Conference on Mechanics and Materials in Design, Jun. 11-15, Albufeira/Portugal, pp: 325-332.

Machalická, K., M. Vokáč and M. Eliášová, 2017d. Experimental analysis of adhesively bonded joints for facade application exposed to accelerated ageing. Proceedings of NE-XT Facades - COST Action TU1403 Adaptive Facades Network - MidTerm Conference, Technical University of Munich, Germany. Molter, Mungenast, Banozic, Englhardt and Klein (Eds.).

Machalická, K., M. Vokáč and M. Eliášová, 2018a. Influence of artificial aging on structural adhesive connections for facade applications. Int. J. Adhesion Adhesives, 83: 168-177.

DOI: $10.1016 /$ j.ijadhadh.2018.02.022

Machalická, K., M. Vokáč, M. Kostelecká and M. Eliášová, 2018b. Structural behavior of double-lap shear adhesive joints with metal substrates under humid conditions. Int. J. Mechan. Mater. Design, DOI: 10.1007/s10999-018-9404-y

Marutaa, E., M. Kandaa and J. Sato, 1998. Effects on surface roughness for wind pressure on glass and cladding of buildings. J. Wind Eng. Industrial Aerodynam., 74-76: 651-663.

DOI: $10.1016 / \mathrm{S} 0167-6105(98) 00059-2$ 
Marysse, C., 2016. Structural adaptive facades. MSc Thesis, Ghent University, Ghent, Belgium,

Modin, H., 2014. Adaptive building envelopes. MSc Thesis, Chalmers University of Technology, Gothenburg, Sweden,

Morales-Beltran, M. and P. Teuffel, 2013. Towards smart building structures: adaptive structures in earthquake and wind loading control response-a review. Intell. Build. Int., 5: 83-100. DOI: $10.1080 / 17508975.2013 .778193$

Park, J.J. and B. Dave, 2014. Bio-inspired parametric design of adaptive stadium facades. Australian J. Constr. Econom. Build. Conf. Series, 2: 27-35. DOI: 10.5130/ajceb-cs.v2i2.3886

Pravdová, I., K. Machalická and M. Eliášová, 2016. Steel-glass structural elements with a new generation of adhesives. Proceedings of the Challenging Glass 5 - Conference on Architectural and Structural Applications of Glass, Ghent University, Belgium, pp: 201-208. Belis, Bos and Louter (Eds), ISBN 978-90-825-2680-6. DOI: $10.7480 / \operatorname{cgc} .5$

Rajčić, V. and R. Žarnić, 2015. Racking testing of an innovative hybrid load-bearing panel composed of laminated glass inserted in a CLT frame. Proceedings of the 'Adaptive Facade Network Europe' Industry Workshop. Luible, Overend, Aelenei, Knaack and Perino and Wellershoff (Eds.), TU Delft Open, ISBN-13: 978-94-6186581-6, pp: 43-43.

Rodrigues, A., S. Jordão, V. Dias da Silva, D. Rodrigues and C. Leitão et al., 2017. Structural adhesive SikaFOrce $\quad 7710 \quad$ L100-Experimental characterization. Proceedings of NE-XT facades COST Action TU1403 Adaptive Facades Network Mid-Term Conference, Technical University of Munich, Germany. Molter, Mungenast, Banozic, Englhardt and Klein (Eds.).

Santarsiero, M., C. Bedon and C. Louter, 2018. Experimental and numerical analysis of thick embedded laminated glass connections. Composite Structures, 188: 242-256.

DOI: $10.1016 /$ j.compstruct.2018.01.002

Santos, F., C. Bedon and M. Sacadura, 2016. Adaptive glass panels using shape-memory alloys. Glass Structures Eng., 1: 95-114.

DOI: $10.1007 / \mathrm{s} 40940-016-0016-3$
Senatore, G., P. Duffour, P. Winslow and C. Wise, 2018. Shape control and whole-life energy assessment of an 'infinitely stiff' prototype adaptive structure. Smart Mater. Structures, 27: 015022-015022. DOI: $10.1088 / 1361-665 \mathrm{X} / \mathrm{aa} 8 \mathrm{cb} 8$

Senatore, G., P. Duffour, P. Winslow, S. Hanna and C. Wise, 2013. Designing adaptive structures for whole life energy savings. Proceedings of the 5th International Conference on Structural Engineering, Mechanics and Computation, Sept. 2-4, Cape Town, South Africa, pp: 2105-2110.

DOI: $10.1201 / \mathrm{b} 15963-380$

Senatore, G., P., Duffour, S. Hanna, F. Labbe and P. Winslow, 2011. Adaptive structures for whole life energy savings. J. Int. Assoc. Shell Spatial Structures, 52: 233-240.

Sobek, W. and P. Teuffel, 2001. Adaptive Systems in Architecture and Structural Engineering. Proceedings of the 8th SPIE's Annual International Symposium on Smart Structures and Materials, Newport Beach, CA, United States, pp: 36-45

Teuffel, P., 2011. From adaptive to high-performance structures. Proceedings of the 6th International Symposium on Steel Structures, Nov. 3-5, Seoul, Korea.

Udrea, I., C. Croitoru, I. Nastase, R. Crutescu and V. Badescu, 2016. An Adaptive Thermal Comfort Model for the Romanian Climate. In: Mediterranean Green Buildings and Renewable, Energy, Springer International Publishing, Switzerland, pp: 921-930.

Velasco, R., A.P. Brakke and D. Chavarro, 2015. Dynamic Façades and Computation: Towards an Inclusive Categorization of High Performance Kinetic Façade Systems. Proceedings of the 16th International Conference, Computer-Aided Architectural Design Futures, Jul. 8-10, São Paulo, Brazil, pp: 172-191. DOI: 10.1007/978-3-662-47386-3_10

Wada, B.K., J.I. Fanson and E.F. Crawley, 1990. Adaptive structures. Mech. Eng., 112: 41-46. DOI: 10.1177/1045389X9000100202

Zhang, X. and C. Bedon, 2017. Vulnerability and protection of glass windows and facades under blast: Experiments, methods and current trends. Int. J. Structural Glass Adv. Mater. Res., 1: 10-23. DOI: $10.3844 /$ sgamrsp.2017.10.23 